\title{
The Evental Subject: The Concept of the Human Person in Alain Badiou's Event Metaphysics
}

Kenneth C. Masong

\section{ABSTRACT}

An individual is not a subject. What constitutes the subject as subject is the happening of event and the way this happening transforms the insularity of the individual into the "eventality" of the subject. For Alain Badiou (b. 1937), a true subject is one that is subjectivized by the happening of the event and the subject's continuous fidelity to this same event. This essay explores the concept of the human person in Alain Badiou's philosophy. In order to achieve this, a broad overview of Badiou's Ontology of the Event is necessary in order to locate his philosophical anthropology. What follows is a discussion of Badiou's dynamic conception of an individual as a becoming-subject in relation to an event, a relation characterized by fidelity to the event. This unique philosophy of the human person finds its singular exemplar in the New Testament figure of St. Paul of Tarsus. The conclusion of the essay brings Badiou's philosophy of the event, subject and truth into the domain of religious discourse where, interestingly, his philosophy finds a genial fertile ground for further exploration.

KEYWORDS: Alain Badiou, Event Metaphysics, Neo-Paulinism, Truth, Religion, Philosophy of the Human Person

On February 25, 1986, a bespectacled woman dressed in yellow was sworn in as the $11^{\text {th }}$ President of the Republic of the Philippines amidst a rejoicing crowd. It was the culmination of a popular protest against massive electoral fraud in the then recently concluded snap elections. After Marcos inaugurated himself as President, a whole nation that was mired in poverty saw the end of twenty long years of the Marcos regime. At the center of the kaleidoscopic happenings that constitute the event of the 1986 EDSA People Power Revolution is the iconic figure of a "plain housewife and mother of five" 
whose rise to the nation's highest office is epic in scope. One could say that in the person of Corazon C. Aquino, wife of Benigno Aquino, Jr., one discovers an exemplary figure of an evental subject. Her transformation is a radical change in life that brims over into the history of the entire nation. An event such as this and the evental subjects it gives birth to comprise the philosophic theme of Alain Badiou's concept of the human person. Regardless of the scale and magnitude of happenings, it is the quality of ingression of events into the intimate lives of individuals that founds an evental subject.

This essay explores the concept of the human person in Alain Badiou's philosophy. In order to achieve this, a broad overview of Badiou's Ontology of the Event must be discussed in order to situate his philosophical anthropology. What follows then is a discussion of Badiou's dynamic conception of an individual as a becoming-subject in relation to an event, a relation characterized by fidelity to the event. This discussion of becoming-subject is typified in the well-known first-century life of St. Paul of Tarsus. Badiou is one of the $20^{\text {th }}$-century philosophers who have returned to the Apostle to the Gentiles in order to draw a wealth of philosophic themes relevant to contemporary philosophy, a return now labeled "Neo-Paulinism." For Badiou, as reflected in Epistles of St. Paul, one finds the foundation of universalism and the very model of an evental subject, that is, a subject understood as "a universal singularity." The concern for both the universal and the singular becomes relevant in view of Badiou's project of reconfiguring the category of the subject as the "local configuration of a generic procedure from which a truth is supported." That Badiou seeks to unveil the intimate link between the subject and truth is rather unforeseen, especially since to the monolithic universalizing of the category of truth is anathema for postmodern philosophy. The conclusion of the essay brings Badiou's philosophy of the event, subject and truth to the domain of religious discourse where, interestingly, his philosophy finds a genial, fertile ground for further exploration.

\section{Badiou and the Ontology of the Event}

Badiou's philosophy of the event is a "philosophy of the extraordinary" (Hallward, "Generic Sovereignty" 88). He traces a line of argumentation concerning the event that conjoins the idea of singularity with that of the generic. 
In this respect, he does not conceptually turn sharply from Deleuze's metaphysical diagnosis that "[t]he function of singularity replaces that of universality" (Deleuze, "A Philosophical Concept" 95). One may recall that for Deleuze singularity is distinguished from the specific and the merely individual or particular because the latter terms remain fraught with shadows of relations and contexts. As Badiou claims, "[e]very particularity is a conformation, a conformism" (Saint Paul 110). Singularity formalizes an instance of universality because it is disinterested, punctual, insular. The disinterestedness of singularity fixes itself in place as the creditable regent of the suspect universality because absolutized in its uniqueness, the idea of the singular passes for the most indistinct, indiscernible, the generic. This is the term that has come to substitute the philosophical jargon of the universal in Badiou's lexicon. Its importance lies not simply in its instance of replacement, but rather is crucial for it founds the very being of truth in Badiou. He says,

[t]he term 'generic' positively designates that what does not allow itself to be discerned is in reality the general truth of a situation, the truth of its being, as considered as the foundation of all knowledge to come. 'Indiscernable' [an equivalent of 'generic' for Badiou] implies a negation, which nevertheless retains this essential point: a truth is always that which makes a hole in a knowledge. (Being and Event 327) ${ }^{1}$

In Hallward's able concession, "Badiou's own philosophy of a generic singularity is perhaps the most rigorously argued, most exacting, most original contribution" to the metaphysics of event ("Generic Sovereignty" 87).

Badiou's philosophy of the event is extraordinary on two counts. On the one hand, he thinks of the event on the level of metaphysics, but does not render it an ontological status that Leibniz (monad), Whitehead (actual occasion) and Deleuze (the fold) would give it. The event renders possible the emergence of truth (through what he calls "generic procedures"), but is not itself "ontologized" in the sense that it becomes a unit explicable as the metaphysical building block of reality. Although he is critical of the metaphysics

${ }^{1}$ Furthermore, Badiou writes that "une singularitésans prédicat, d'une infinité sans détermination ni hiérarchie immanente, ce que j'appelle le générique” (D’un désastre obscur 13-14). 
of substance, ${ }^{2}$ he charts his own path of response, not by way of flux or fold, but through the surprising route of the mathematical notion of a transfinite set theory. It is in this respect that Badiou's own properly philosophical task becomes "metaontological" because for him, "mathematics is ontology" (Being and Event 15). It is not pertinent here to explore deeply into Badiou's metaphysics, especially as it is laid out in his magnum opus, L'être et l'événement (1988, translated as Being and Event, 2005). We will only discuss certain important notions that are exigent in order to prepare the ground for Badiou's discussion of the event and the evental subject.

Perhaps it is because of Whitehead's mathematical background that he ends up with a metaphysics that essentially becomes atomistic. To think of numbers is to think of the singular and how this enters into relation with elements and variables of an algebraic argument. Badiou's mathematical interest leans toward set theory and what he tries to do is to draw the philosophical implications of this theory into a veritable metaphysics. Taking leave of the various controversies that populate the corpus of set theory, what this theory essentially postulates is that "there is really only one fundamental notion: the ability to regard any collection of objects as a single entity (i.e., a set)" (Devlin 2). Set theory is, needless to say then, about set, that is, to think of reality in terms of belonging and inclusion. It is collective thinking. Being or existence in this regard is not an essential attribute of an entity (or element), but is a result of its belonging to a particular set. The link between ontology and mathematics lies in the observation that if ontology is thinking of being qua being, what is needed from the domain of mathematics is a theory that enables one to think of the multiple as multiple. In set theory, it is not necessary to know the precise number of elements in a set. Particularly in transfinite set theory the notions of infinity and set are combined. In here, there is the possibility of thinking both a set of infinite elements, and the infinity of sets itself. Set theory makes possible the thinking of the abstract form of multiples as multiples (rather than multiples of multiples) because every element of a set is itself a set. To regard a whole and divide it into its elements discloses that, going down the scale, the smallest element is also a set. There is only one limit to this, the stopping point which is an empty set, the void (written by Badiou as $\varnothing$ ). It is on this respect that Badiou's ontology starts with the dismissal of God who

${ }^{2}$ See for example the following words of Badiou: "Dé-substantialiser les vérités sans les transformer en jeux de langage" ("Dix-Neuf Réponses" 263). 
is identified as the ultimate One. If being is multiple, then God (who is One) cannot be because he does not belong to any set. God is not a set, and hence cannot exist. Badiou here was radicalizing the pronouncement of Nietzsche that God is dead. ${ }^{3}$ In Badiou, "there is only one type of presentation of being: the multiple" (Being and Event 44). As he would explain elsewhere:

What ontology tells us, in the theory of the purely multiple, is that, inasmuch as a multiple exists, we can only declare its existence inasmuch as it belongs to another multiple. To exist as a multiple is always to belong to a multiplicity. To exist is to be an element of. There is no other possible predication of existence as such. The immediate consequence is that to exist is to be in a situation. ("Politics and Philosophy" 130)

The dismissal of God in Badiou's ontology of the multiple is grounded not only in his definition of what it means to exist. It was also programmatic, a form of laicization of the idea of the infinite. The affirmation of the multiple in Badiou and the attendant infinity of these multiples as multiples are steps in the desacralization of the infinite which is traditionally located in the divine, that is, in the immeasurable, inconceivable divine Whole or One. ${ }^{4}$

That there is an intrinsic link between the multiple and its situation explains on the other hand why Badiou's theory of the event is extraordinary: The event is included in a situation but it does not belong to it. The "essence of the event is to be undecidable with regard to its belonging to the situation, an event whose content is the eventness of the event... cannot, in turn, have any other form than that of indecision" (Being and Event 193). What an event presents is a break, a scission, unpredictable and irreducible to its locus of emergence. The extraordinariness of the event is manifested because there is required a subjective intervention, or its belonging to its situation is essentially

${ }^{3}$ It needs to be noted here though that for Badiou, the death of God in the death of Christ effectuates the solidarity of God with humanity (see Saint Paul 69).

${ }^{4}$ As Hallward summarizes: "Since there is no God, if the conventionally divine attribute of an 'actual infinity' applies to anything at all, it must apply, very simply, to all that is. The death of God implies not a disillusioned or postenchantment acceptance of the human condition but rather the rigorous affirmation of our own infinity. No longer are we to consider ourselves finite creatures whose particularity emerges in the pathos of our relation to a transcendent infinity. Instead, we already exist in an 'absolutely flat' infinity" (Badiou 7). 
undecidable. An event must rally the aid of a subject who, proclaiming the existence of the event itself, assures it of its truth. This means that the truth of the event will have been shown in so far as someone will have made it true by its proclamation. As Žižek would summarize it, a subject is "the agent who, on behalf of the Truth-Event, intervenes in the historical multiple of the situation and discerns/identifies in it signs-effects of the Event. What defines the subject is his fidelity to the Event: the subject comes after the Event and persists in discerning its traces within his situation" (130). Furthermore, an event breaks the ordinariness of causal sequence of multiples in order to introduce novelty and freshness of historical happenings. This is hugely reflected in Badiou's intellectual biography, for example, in the influence of the works of Samuel Beckett and the cultural and intellectual legacy of May '68.

For Badiou, we intermittently encounter events in life wherein we experience "a sort of subjective blow [frappe subjective], the imprint of which is ineffaceable" (qtd. in Gibson 5). He said these words in reference to the radical impact that the literary works of Beckett had upon him. After around forty years since his first encounter with the dramatist, he is still able to say to himself, in the words of Arthur Rimbaud: "J'y suis, j'y suis toujours" (qtd. in Gibson 2). One may call this a Beckett-event in Badiou's intellectual genealogy. The originary encounter with the literary consciousness of Beckett passes into the very mode of Badiou's thinking, infecting him, and contaminating his ideas. Badiou has this peculiar sensitivity to the many events that inflect human comportment. Like so many French intellectuals contemporaneous to him, his own socio-political thoughts and ethico-philosophical orientations are influenced by the event of May '68. He recalls:

Yes we were the genuine actors, but actors absolutely seized by what was happening to them, as something extraordinary, something properly incalculable.... Of course, if we add up the anecdotes one by one, we can always say that at any given moment there were certain actors, certain people who provoked this or that result. But the crystallisation of all these moments, their generalisation, and then the way in which everyone was caught up in it, well beyond what any one person might have thought possible-that's what I call an evental dimension. None of the little processes that led to the event was equal to what actually took place...; there was an extraordinary change of scale, as there always is in every significant event.... Yes, we are actors, but 
in such a way that we are targeted by, carried away by, and struck by [atteint par] the event ("Politics and Philosophy" 125-26).

Badiou and other French intellectuals of his generation were both actors and spectators in this "public festival" (Taylor 205) which in French intellectual history came to be called "the events of May 1968" "Politics and Philosophy" 126). His encounter with the works of Beckett, his first-hand experience of May '68, his discovery of Georg Cantor's set theory, etc. all constitute the subject Badiou that one encounters, meets, dialogues with in contemporary philosophy. These events constitute his "becoming-subject" (devenir-sujet). It was not simply the revision of metaphysics that Badiou aims at in Being and Event, but likewise the reconfiguration of the subject in a process he calls "subjectivization."

\section{Becoming-Subject: Fidelity to the Event}

Being, Subject, and Truth are concepts inextricably linked in Badiou's oeuvre; they are "the three noedal concepts" of philosophy which are linked together by the notion of event (Manifesto for Philosophy 32). In his Being and Event, he sought to explicate his ontology of the multiple based on the mathematical principles expounded in set theory. Badiou's thought is hard to pigeonhole because it traverses various disciplines: from Maoism in sociopolitical thought, to set theory in mathematics and event in metaphysics. His own statement that "mathematics is ontology" seems to collapse two traditionally discrete studies of thought that one wonders where exactly he situates his own discourse himself. On the question of Being, Badiou's thought traces itself within the tradition of Western philosophy because he recognizes debt to Heidegger. Ontology is the science of being qua being. On the question of Event, contemporary philosophy has been replete with a rethinking of this elusive concept "being," from both metaphysicians and phenomenologists. But for Badiou, the more significant word in the title of his magnum opus is not so much Being or Event but rather the very identity and character of the "and" that conjoins the two. This "and" is the Subject, or at least speaks of the

${ }^{5}$ Badiou's French "subjectivation" in most English publications is either maintained as such or translated as "subjectivization." Since neither appears in the Oxford English Dictionary, and only the latter appears in the Merriam-Webster, this research translates the French as "subjectivization." 
process of what he calls subjectivization; that is, the bridging of that which is not (event) into that which is (being) by the subject's naming, intervention, and fidelity to the event. For Badiou, truth is not a substantial knowledge, but rather a process, a procedure that finds its characteristic link in the subject who proclaims it as truth, and as such, it is said to be universal. This truth procedure is reflected in the four domains or generic procedures in the invention of truth: ${ }^{6}$ politics, science, art, and love. A generic procedure refers to "the passage from the old to the new. It is a procedure which aims to assert change" (Barker, Alain Badiou 96).

Badiou's overall philosophical project is to redefine the ontological category of the "subject" into that of "universal singularity" (Saint Paul 13-15). A subject is strictly differentiated from the individual in that when Badiou speaks of the subject, it is "decentered in relation to the individual" (qtd. in Hallward, Badiou 143). It is a singularity without any specificity (and hence can attain to the status of universal) because it is devoid of any relation. It is a subject without a vis-à-vis, that is, without its other. ${ }^{7}$ Departing from the general trend of thought in Western philosophy, talk of the Other and difference (Merleau-Ponty, Irigaray, Ricoeur, Deleuze, Lyotard) is subsumed under the Same. ${ }^{8}$ Modern philosophy's turn to interiority involves the turn to the subject that commenced with Cartesian thought, but not simply a thinking subject detached from the extended world, but one that is unavoidably linked to the world, an "experiencing subject," as Whitehead's metaphysics of experience would suggest. In Badiou, the Subject is brought to a second level wherein its centrality is diffused in its experiencing (in a manner of speaking). Badiou's thought on the subject belongs to what he calls the "second epoch of the doctrine of the Subject." More specifically, he elaborates, that in this second epoch, the subject is

No longer the founding subject, centered and reflexive, whose theme runs from Descartes to Hegel and which remains legible in Marx and Freud (in

${ }^{6}$ Badiou argues that "every truth is an invention" (Handbook 11).

${ }^{7}$ The task that Badiou speaks of in here is "to produce a concept of the subject such that it is supported by no mention of the object, a subject, if I might say, without a vis-à-vis" (Manifesto 93).

${ }^{8}$ In upholding his theory of the generic, Badiou attests to the "Primat du Même sur l'Autre, rejet de la Différence comme principe de classification (le générique, c'est la différence réduite au presque-rien, soit : être de la même présentation). Une vérité est l'errance du Même" ("Dix-Neuf Réponses” 263). 
fact, in Husserl and Sartre). The contemporary Subject is void, cleaved, asubstantial, and ir-reflexive. Moreover, one can only suppose its existence in the context of particular processes whose conditions are rigorous. (Being and Event 3)

In reconfiguring the category of the subject Badiou is linking it with his notion of event and the truth that emerges from this procedure. He himself clarifies that his project is to "refound a theory of the Subject that subordinates its existence to the aleatory dimension of the event as well as to the pure contingency of multiple-being without sacrificing the theme of freedom" (Saint Paul 4). As he says, the subject's existence is supposed only within the context of a process, or what he calls truth-procedures, namely, the subjectivization of an individual in relation to the event that pulls his being in a radical transformation of the self. For Badiou, there is nothing substantial in the subject other than becoming the "local configuration of a generic procedure from which a truth is supported" (Being and Event 391).

The concept of a generic procedure is important because it operates in the production of truth (as truth is always an invention). There are said to be four generic procedures (or "conditions of philosophy" which are synonymous to these procedures), namely, love, art, science and politics (see Being and Event 16). These are fields or dimensions that give birth to truth. They are "conditions of philosophy" because philosophy as such is not productive of truth. Indeed, truth is not the object of philosophy. Philosophy's task for Badiou is "the apprehension in thought of the conditions for the practice of thought in its different registers" (Metapolitics 86). It is to demonstrate the "compossibility" of the truths that the generic procedures generate in a particular epoch. ${ }^{9}$ It is not just the task of philosophy to organize or systematize; it is its essential vocation. ${ }^{10}$ In this instance, truth can be amorous, artistic, scientific or political, but it cannot be philosophical. ${ }^{11}$ Badiou maintains that "what is proper to

${ }^{9}$ This is precisely the précis of Badiou's Le siècle (2005, translated in English as Century 2007).

10"Je défends dans le Manifeste [pour la philosophie, 1989] l'idée qu'au fond il y a nécessairement une volonté systématique de la philosophie, même si l'apparence extérieure des textes de philosophie peut parfois donner l'impression contraire. La philosophie n'existe que quand elle propose une compossibilité de ses conditions, la vocation systématique est inévitable et fait partie de l'essence même de la philosophie." "L'entretien De Bruxelles" 25)

11 "Philosophy's relation to art, like its relation to every other truth procedure, comes down to showing it as it is. Philosophy is the go-between in our encounters with truths, the procuress [la 
philosophy is not the production of universal truths, but rather the organization of their synthetic reception by forging and reformulating the category of Truth" (emphasis added, Saint Paul 108).

One dimension of thought peculiarly absent in Badiou's list of generic procedures is that of religion. Where does Badiou situate the "truth of religion"? In Badiou, the event of the religious and the thinking of the universal subject coalesce in his interesting and relevant treatment of the biblical figure Paul of Tarsus, to which we turn in the next section.

In order to illustrate the contours of a theory of the event of the religious, one strategy is to cite a particular example within a specific religious tradition. Badiou is a relevant speaker in this conversation not simply because of his articulation of evental subjectivization, but also because he deliberately speaks of the event of the religious in his book on Paul, who is a personality in the Christian tradition attracting attention among contemporary philosophers. He is one striking individual in Christianity whose life is characterized by a singular and originary event. Caravaggio depicts him as having fallen from a horse and in the act of encountering an event. Paul became a convert to it and gave it a name-"Christ is risen." He started faithfully to proclaim its truth beyond the Jewish frontier and wrote the earliest material attestation to the Christian faith, which antedates the canonical Gospels by a few decades. All these happened without even knowing Jesus in person as the other apostles did. It is the singularity of Paul, and hence the universality that he bears, that Badiou discerned in him the foundation of universalism. In order to articulate evental subjectivization in the possible event of the religious, it is to this work that we now turn, Alain Badiou's Saint Paul: La fondation de l'universalisme (1997, translated as Saint Paul: The Foundation of Universalism, 2003).

\section{Pauline Event}

Religion in general and Christianity in particular, are of singular importance in the thinking of the event (as religious revelation is an exemplary instance of event), in thinking the subject (since one finds the passionate mili-

maquerelle] of truth. And just as beauty is to be found in the woman encountered, but is in no way required of the procuress, so it is that truths are artistic, scientific, amorous, or political, and not philosophical." (Handbook 9-10) 
tancy Badiou seeks among religious founders like Saint Paul founding Christian communities in Antioch and surrounding localities), and in thinking the truth (since Badiou follows Lacan's contention that "if no religion were true, Christianity, nevertheless, was the religion which came closest to the question of truth" [Being and Event 212]). In Badiou, Christianity is of singular importance in his philosophy of event because "[a]ll the parameters of the doctrine of the event are thus disposed within Christianity" (Being and Event 212).

Badiou admits that he considers Paul, not as an apostle or a saint, but rather as a figure of primary importance in New Testament times. For him, "Paul is a poet-thinker of the event" [penseur-poète de l'événement] (Saint Paul 2). He is "the man for our time," contemporary to us even though the temporal, cultural, social and religious gap existing between us and him may be temporally extensive and culturally deep. As Badiou would put in the mouth of Pier Paulo Pasolini: "Paul is our fictional contemporary because the universal content of his preaching, obstacles and failures included, remains absolutely real" (Saint Paul 37). It is indeed striking that a number of contemporary thinkers beyond the walls of religious and theological discourse have started to take interest in this New Testament author such that another label has come to populate the philosophical lexicon of cultural theory: "neo-Paulinism."12 This is even more striking since a good number of these neo-Paulinists are denizens of the atheist, far-left, materialist camp (Badiou himself, Žižek, and Agamben). Their own retrieval of the Pauline legacy has almost nothing in common with the "alleged fidelity" to Pauline thought among Christian denominations. Nonetheless, this has not hampered these neo-Paulinists to retrieve essential elements of thinking germane in Paul's epistles and "forgotten" by the traditional bearers of his legacy. ${ }^{13}$ For Badiou, Paul becomes our contemporary because his thinking provides answers to the impasse of the

\footnotetext{
${ }^{12}$ See the two-part essay by Moreiras, "Children of the Light." It was Moreiras who, in the aforementioned articles, gave the nomenclature of "neo-Paulinism" to contemporary (political) philosophy's interest in Saint Paul that is discernible in Alain Badiou, Slavoj Žižek and Giorgio Agamben. In reference to these three political philosophers, see also Blanton "Disturbing Politics".

${ }^{13}$ As one New Testament scholar comments on this Pauline retrieval: "I find it much more necessary at the moment to allow this newly resurrected Paul, returning outside the traditional boundaries of religious propriety (which is to say, of course, religious propriety), to constitute a fundamental challenge to alleged ecclesiastical faithfulness to the Pauline kerygma. Rather than trying to fix any of our former identitarian boundaries, most of all the difference between "religion" and "secularity," I want to praise these "fighting Paulinists," if not for no other reason than to provoke the religious to a kind of jealousy about what they are missing" (Blanton 5).
} 
current situation, especially with regard to the truth to which the contemporary world is said to be hostile (see Saint Paul 12). The most basic condition of the present world to which Badiou is responding with regard to his retrieval of Saint Paul has to do with the thinking of the truth of the event. Badiou argues that the "progressive reduction of the question of truth (and hence, of thought) to a linguistic form, judgment... ends up in a cultural and historical relativism that today constitutes at once a topic of public opinion, a 'political' motivation, and a framework for research in the human sciences" (Saint Paul 6).

Badiou's philosophy of the event draws inspiration from the belief in the "strong, simple idea that every existence can one day be transfigured by what happens to it and subsequently devote itself to that which is valid for all"14 (Saint Paul 66). The importance of Paul in the thinking of the event starts with his own conversion along the Damascus road. Paul was not converted by other followers of Jesus. The Damascus story narrates something that happened to Paul. "The event-'it happened,' purely and simply, in the anonymity of a road-is the subjective sign of the event proper that is the Resurrection of Christ" (Saint Paul 17). The event as such, eventum tantum, is Christ's Resurrection and it is this that Paul proclaims, but the subjective link that connects the doctrine with his existence, with his institution as a new subject, is the conversion while traveling the road towards Damascus. There is no seeking of proof in the two events (as if to say there is a space for demonstration of the historicity of the Resurrection and the Vision he had on the road). ${ }^{15}$ Through the subjective sign which is evental itself, Paul was constituted into an Apostle, with an unshakeable conviction, by the event proper. It was his becoming-subject: "turning away from all authority other than that of the Voice that personally summoned him to his becoming-subject [devenir-sujet],

${ }^{14}$ In French the text reads as follows: "l'idée, simple et forte, que toute existence peut un jour être transie par ce qui lui arrive, et se dévouer dés lors à ce qui vaut pour tous" (70). Brassier translates the phrase "être transie" into "be seized," while Hallward prefers to render it into "be transfigured" (Badiou xxiii). The translation of the text in the main body maintained Hallward's rendition because it approximates more Badiou's general idea that a subject is transformed by events that s/he encounters in life. Brassier's translation suggests as if the encounter with the event effects a mere suspension of being, while Badiou suggests something more dynamic, originary and life transforming, the very kind that one finds in Saint Paul's conversion on the road to Damascus.

15 "For Paul, the event has not come to prove something; it is pure beginning. Christ's resurrection is neither an argument nor an accomplishment. There is no proof of the event; nor is the event a proof" (Saint Paul 49). 
Paul leaves for Arabia in order to proclaim the gospel, to declare that what took place did take place. A man armed with a personal event, who has grounds for declaring that impersonal event that is the Resurrection" (emphases added, Saint Paul 18-19). One sees here that in Paul's conversion story, there was a transition from the personal to the impersonal. It was a movement from the singular to the universal which is characteristic of the truth procedure that Badiou speaks of. Between the singular and the particular, there is a dynamic relation whereby one becomes dependent on the other. ${ }^{16}$ The universality of a truth procedure necessitates a subjective recognition of its singularity; it needs a subjective intervention. To any person to whom the kerygma is preached, he or she cannot be indifferent to it. Before the event of the Resurrection, there are no degrees of participation. "Either one participates in it, declaring the founding event and drawing its consequences, or one remains foreign to it. This distinction, without intermediary or mediation, is entirely subjective.... Such is the price for truth's status as a universal singularity" (Saint Paul 21-22). The power of the event shakes one as if from a slumber, disturbing traditional truths; it rocks the boat of complacency demanding allegiance or otherwise. The singularity of the truth comprises its uniqueness by transforming subjects to become its preachers of its truth. But at the same time, the truth of the event (or what Badiou calls "postevental truth" because it is what is inferred from the Christ-event) is not just singular but is likewise generic. As Paul famously preaches: "There is neither Jew nor Greek..." (Gal. 3.28). The generic character in the Christ-event was intimated in the observation that though Jesus was a Jew, both religiously and culturally, the event itself traversed beyond Jewish law and prophetism. The Christ-event is not a property of the narrow assemblage of Jewish heritage, nor will its preaching ever be centered in Jerusalem (Paul did preach the kerygma to the "pagans"). ${ }^{17}$ "In his eyes," Badiou avers, "the event renders prior markings obsolete, and the new universality bears no privileged relation to the Jewish community" (Saint Paul 23). Although the Christ-event has for its context the religious, social, and political trappings of the history of the people at that time, the essence of the truth procedure

16 "A truth procedure is only universal insofar as it is supported, at that point through which it indexes the real, by an immediate subjective recognition of its singularity." (Saint Paul 22)

${ }^{17}$ Badiou commented that after the first meeting of Paul with the other Apostles in the "Jerusalemite center," he did not limit his preaching to the Jewish people, but all the more extended his activity beyond the vicinity of Jerusalem. "The ex-centered dimension of Paul's action is the practical substructure of his thought, which posits that all true universality is devoid of a center" (Saint Paul 19). 
and its extension by way of effect are not commensurate and reducible to this narrow context.

With these few remarks, one may outline the specific features of the event and identify its characteristics in Badiou. Firstly, Badiou presents a peculiar understanding of event because he contrasts it with being: The event is that which is not being qua being (cf., Being and Event 173). ${ }^{18}$ An event "takes place that belongs to a wholly different dimension-that, precisely, of non-Being" (Žižek 130). Why is this? Recall that existence is that which can be counted, that which belongs to a set. An event does not belong to any set; it is self-founded (or non-founded for both are the same thing). Though it has an evental site (Jerusalem in the case of the Christ-event), it does not belong to the situation where it finds itself. Although an event is not being, it does not, however, mean that it is nothing. It is still what is called a multiple. It is counted as one in the situation where it finds itself, though it does not belong there. It is a skandalon, "an undecidable, chaotic intrusion that has no place in the State of the Situation" (Žižek 138). In this respect, it has an "ephemeral" character in relation to its situation. ${ }^{19}$ It is a midway between being and nothingness (or what he calls the "void"); an event is "supernumerary" (Being and Event 178). The Christ-event was not something that fell off from the trunk of the commonplace. Indeed stories similar to the life and teachings of Jesus were common during that time, but the Resurrection itself, and the postevental truth that marked its trace, was evental interruption, something that broke any expectation (Heidegger's "ekstatis," Levinas' "dia-chrony"). ${ }^{20}$ It came, in the words of Dastur, as an "impossible possible:" "The event, in its internal contradiction, is the impossible which happens, in spite of everything, in a terrifying or marvelous manner. It always comes to us by surprise, or from that side whence, precisely, it was not expected" (Dastur 183).

${ }^{18}$ In an interesting instance, Badiou notes that Paul, in his founding of the Christian event has anticipated Heidegger's critique of onto-theology. "One must, in Paul's logic, go so far as to say that the Christ-event testifies that God is not the god of Being, is not Being. Paul prescribes an anticipatory critique of what Heidegger calls onto-theology, wherein God is thought as supreme being, and hence as the measure for what being as such is capable of" (Saint Paul 47).

19 "As something that cannot be recognized as one in a situation, an event is the (necessarily ephemeral) presentation of inconsistency in the situation. Though it thus indicates the true being of the situation, an event must for that very reason count as nothing for this situation." (Hallward, Badiou 115)

${ }^{20}$ For Badiou, "waiting is pointless, for it is of the essence of the event not to be preceded by any sign, and to catch us unawares with its grace, regardless of our vigilance" (Saint Paul 111). 
Secondly, this supernumerary character of event is exigent in Badiou's ontology of the multiple because this constitutes the event as the source of novelty. It provides for the concept of freshness and newness. What the event reveals is the "edge of the void." It is from this edge of nothingness that an event emerges as an alien avenue for possibilities. It is alien because the event is not reducible to the situation where it finds itself. Hence, events arise from pure chance. It is "purely hazardous [hasardeux], and...cannot be inferred from the situation, yet which is nevertheless a fixed multiple, a number, that nothing can modify once it has laid out the sum-'refolded the division'-of its visible faces" (Being and Event 193). The structure of an event provides for the repetition, but the event itself breaks this structure providing for novelty and freshness. The event ensures that there is creatio ex nihilo because the event as the "void of the situation" is that aspect of the situation that has no regard for the prevailing status quo. This is noted in Badiou's comment concerning the Jerusalem conference and how it is said to be genuinely foundational. He remarks,

The Jerusalem conference is genuinely foundational, because it endows Christianity with a twofold principle of opening and historicity. It thereby holds tight to the thread of the event as an initiation of a truth procedure. That the event is new should never let us forget that it is such only with respect to a determinate situation, wherein it mobilizes the elements of its site (Saint Paul 25).

Once an event happens, a new chapter is drawn, but it will only continue in so far as it gains a subject that will have proclaimed its truth, that will have wagered with regard to its existence. Attention to the tense of the previous sentence brings us to the third character of event, that of temporality. An event as happening is true not in the present tense but in the future anterior. ${ }^{21}$ The event "would have been presented" ["il aurait été présenté"] (Being and Event 195). If an event is a stranger to its situation, it will arrive at the same situation as its home only in so far as a subject names it so, or intervenes through nomination. This explains why an evental promise necessitates an evental

${ }^{21}$ According to Žižek the specific temporality of generic procedures involves a "temporal loop": "fidelity to the event enables them [the generic procedures] to judge the historic multiple from the standpoint of plenitude to come, but the arrival of this plenitude already involves the subjective act of Decision-or, in Pascalian, the 'wager' on it" (144). 
subjectivization. There is a lacuna in the event which needs to be filled; it is "empty" because there is no reference still. In the words of Žižek: "The naming of the Truth-Event is 'empty' precisely in so far as it refers to the fullness yet to come" (136). In this scenario then, an event's tenure is accomplished only in the future that is immanent to it. ${ }^{22}$ This illustrates what we discern in Deleuze's fold: that every folding promises an unfolding and refolding. The essential truth of an event, the very character of the truth procedure in this instance, lies not in facticity but in subjective disposition, in the subject's comportment to the originary event. Before the Christ-event, we are apostles, not Greek philosophers or Jewish prophets. The truth-event is not about facts, but about the opening of universal possibilities inviting actualization in subjects. As Badiou notes,

[The Resurrection] is pure event, opening of an epoch, transformation of the relations between the possible and the impossible. For the interest of Christ's resurrection does not lie in itself, as it would in the case of a particular, miraculous fact. Its genuine meaning is that it testifies to the possible victory over death, a death that Paul envisages...not in terms of facticity, but in terms of subjective disposition. Whence the necessity of constantly linking resurrection to our resurrection, of proceeding from singularity to universality and vice versa: 'If the dead do not resurrect, Christ is not resurrected either. And if Christ is not resurrected, your faith is in vain' (Cor. I.15.16). In contrast to the fact, the event is measurable only in accordance with the universal multiplicity whose possibility it prescribes... The apostle is then he who names this possibility. (Saint Paul 45)

Note here the quotation that Badiou draws from Paul's epistle: "If the dead do not resurrect, Christ is not resurrected either." If the event is an issue of (historical, time-bound) fact, then, the verity of Christ's resurrection is autonomous from the resurrection of others. But such is not precisely the idea of event that Badiou pursues. Subject, event, and truth are inextricably linked in a specific generic procedure. The eventum tantum is neither punctual nor insular (in Taylor's sense). It is indiscernible and the relation to its situation is undecided. There is fixity of an event in a situation, but its presence is undecidable because

${ }^{22}$ This almost echoes Hegel's statement: "The owl of Minerva spreads its wings only with the falling of the dusk" (Philosophy of Right 13). 
it belongs to its essence to be so: "the essence of the event is to be undecidable with regard to its belonging to the situation, an event whose content is the eventness of the event...cannot, in turn, have any other form than that of indecision" (Being and Event 193). This undecidability of an event is explicative of the exigency of what Badiou calls a "subjective intervention." The fourth character of an event is that it needs a subject: "one can only know whether [an event] has taken place inasmuch as one bets upon its truth" (Being and Event 193). An event necessitates a subject who wagers upon its truth. In itself, an event because of its undecidable essentiality cannot be proven or demonstrated. It can only be asserted or declared: "la vérité consiste à le déclarer (et ensuite à y être fidèle)." "Saint Paul" 324-25). This is the intervention of an agent that Badiou speaks of linking inextricably the concept of event with the notion of a subject. The Christ-event creates apostles, and the becoming-subject of these apostles lies not so much in self-constitution, but on how the event itself constitutes the subject by what he proclaims. "It is not the singularity of the subject," avers Badiou, "that validates what the subject says; it is what he says that founds the singularity of the subject" (Saint Paul 53). It is to this fourth character of the event, on the theme of evental subjectivization, that we now turn our discussion.

\section{The Subject as Universal Singularity}

Badiou, who is a militant atheist, has a place for Saint Paul in his materialist ontology, not so much because of the testimony of Christian heritage, but because he considers the apostle as the "fondateur du sujet universel" ("Saint Paul" 323ff). Badiou's reconfiguration of the category of the subject proceeds from his own project of accounting for the recuperation of the concept of truth. The problem with contemporary philosophy is its gnawing distrust for the category of truth, perceiving it as hegemonic and ultimately fascist. Going against the grain, Badiou seeks to rehabilitate truth as the chief category of all possible philosophy. This he accomplishes through the reconfiguration of the subject, defining the latter as "any local configuration of a generic procedure from which a truth is supported" (Being and Event 391).

What are the characteristics defining the contours of Badiou's subject? Firstly, the cause of the subject is an event. ${ }^{23}$ There is no subject prior to an event,

${ }^{23}$ "Qu'est-ce qui cause un sujet ? C'est un événement” (Badiou, "Saint Paul” 332). 
preexisting the latter in temporality and in importance. A "Christian subject does not preexist the event he declares (Christ's resurrection)" (Saint Paul 14). An event becomes the locus for the emergence of subjectivity, but not in a transitive causality as if an event simply "produces" a subject from the immanency of its evental womb. An agent enters into the process of "becoming-subject," but not in passivity; rather through a decision that is a consequence of the undecidability of the Truth-Event. It is an essential character of the event to require a subjective intervention, and the initial subjective movement in this intervention is called "nomination," that is, the naming of the event. ${ }^{24}$ The evental nomination "is the creation of terms that, without referents in the situation as it stands, express elements that will have been presented in a new situation to come, that is, in the situation considered, hypothetically, once it has been transformed by truth" (emphases added, Hallward, Badiou 124). One has to note the phrase "without referents" because the nomination will only be a trace of the event. That which is proper to the eventum tantum will be gone, a "vanished event" [l'événement disparu], (Saint Paul 58) and that which remains will be the evental statement. The Christ-event (that Christ is risen from the dead) has come to pass, and what remains is the evental trace in the form of a statement (one declares "Christ is risen!") that is detached from the event itself. Whitehead notes of this with regard to the triviality of the identity of the event. "[T]he prisoner in the dock," says he, "may be the man who did the deed. But the deed (event) lies in the irrevocable past; only the allegation of it (evental statement) is before the court and perhaps (in some countries) a reconstitution of the crime. Essentially the very deed itself is never there" (Principles of Natural Knowledge 66). It is important for an event to be declared because its eventality essentially ebbs. ${ }^{25}$ Paul's declaration of the Christ-event was not a re-presentation of the eventum tantum; rather, it expressed the elements that would have come to pass in a new situation, but this time, transformed by the Christ-event itself, and this situation would have to require what Badiou called an "operator of faithful connection" (Being and Event 392). In the case of the Christ-event, this operator is the Church: "In Christianity, the Church is that through which connections and disconnections to the Christ-event are evaluated" (Being and Event 392).

${ }^{24}$ As Badiou reiterates, "every subject generates nominations” (Being and Event 397).

${ }^{25}$ Badiou argues that "le seul être de l'événement est d'être déclaré, puisque c'est un 'avoir eu lieu' disparu” ("Saint Paul” 332). 
The second characteristic of the subject is that it is an essentially divided subject: "Le sujet se constitue comme divisé au regard de sa cause [un événement]." ("Saint Paul" 332). Standing before the event, a subject "is the weaving together of two subjective paths, which Paul names the flesh $(\sigma \alpha \rho \xi)$ and the spirit ( $\pi v \varepsilon \cup \tilde{u} \alpha)$. The real in turn, insofar as it is in some way 'grasped' by the two paths that constitute the subject, can be inflected according to two names:

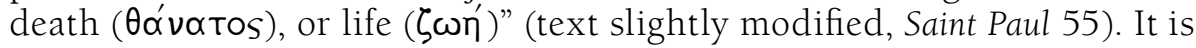
important to note here that for Badiou, Paul's preaching on these two paths that constitute the Christian subject is not about the opposition between the soul and the body, but between life and death. For Badiou there are in essence three discourses: Greek, Jewish, and Christian. ${ }^{26}$ These discourses do not indicate anything associated with race, culture, or nationality. These are "subjective dispositions," (Saint Paul 41) or manners of comportment. The subjective figure constituted by the Jewish discourse is that of a prophet, and it is essentially a discourse of sign, testifying to transcendence. A prophet is someone who speaks to the people on God's behalf, who himself is a sign of the transcendent not readily accessible to the people. A subjective figure constituted by the Greek discourse is that of a wise man, and it is characteristically a discourse of wisdom. However, this wisdom is cosmic "deploying the subject within the reason of a natural totality. Greek discourse is essentially the discourse of totality, insofar as it upholds the sophia (wisdom as internal state) of a knowledge of phusis (nature as ordered and accomplished deployment of beings)" (Saint Paul 41). Both of these discourses of the subject do not attain universality because they presuppose each other ${ }^{27}$ and because they are "two aspects of the same figure of mastery" (Saint Paul 42). Greek discourse is a mastery of totality of the entire cosmos; Jewish discourse is a mastery of the prophet emphasizing literal tradition and interpretation of signs. Either way, both discourses promise salvation in accordance with the law. Here, one enters into a surprising interpretation of the law, subverting legal discourse from the commonly understood universality to that of a discourse within

${ }^{26}$ Later on, Badiou would remark that a fourth discourse is exigent wherein "Paul accomplishes his objective only by defining a fourth discourse, which could be called mystical, as the margin for his own." Nonetheless, this fourth discourse does not essentially occupy a sizeable locus in his discussion and hence will be left out in this argument (Saint Paul 41).

${ }^{27}$ According to Badiou, "the weakness of Jewish discourse is that its logic of the exceptional sign is only valid for the Greek cosmic totality. The Jew is in exception to the Greek. The result is... that neither of the two discourses can be universal, because each supposes the persistence of the other" (Saint Paul 42). 
particularity. In Badiou's reading of Paul, law is the path of the $\sigma \alpha \rho \xi \xi$ and hence only brings $\theta \alpha^{\prime} v a \operatorname{tos}^{28}$ Sin and death entered into the domain of the real only because of the law: "there is no Sin prior to or independent of the Law: what comes before it is a simple innocent prelapsarian life forever lost to us mortal human beings" (Žižek 148). Why is the path of legality an inflection of death? Is it not the case that compliance to the law and conformity to customs and traditions bring peace and harmonious life? For Badiou, the law is the discourse of death because what the law brings is a cyclic logic of perversion. He quotes Paul saying,

What then shall we say? That the Law is sin? By no means! Yet if it had not been for the Law, I should not have known sin. I should not have known what it is to covet if the Law had not said, 'You shall not covet.' But sin, finding opportunity in the commandment, wrought in me all kinds of covetousness. Apart from the Law sin lies dead. I was once alive apart from the Law, but when the commandment came, sin revived and I died; the very commandment that promised life proved to be death to me. For sin, finding opportunity in the commandment, seduced me and by it killed me. (Saint Paul 80)

For Badiou, what Paul is thinking here "points toward a theory of the subjective unconscious, structured through the opposition life/death" (Saint Paul 80). As Žižek comments, "the problem St Paul struggles with is how to avoid the trap of perversion, that is, of a Law that generates its transgression, since it needs it in order to assert itself as Law" (148). The notion of a law entails an internal logic, working within the unconscious, wherein for law to be valid, it has to generate its own contradiction or transgression. The very act of offense brings a perverted pleasure of having contravened the law, but this same perversion is internally lodged within the dynamic of law; it is exigent to it. ${ }^{29}$ The challenge that Saint Paul faces then is how exactly can one escape from this

${ }^{28}$ Badiou asks, "But why is it necessary to reject law onto the side of death? Because considered in its particularity, that of the works it prescribes, the law blocks the subjectivation of grace's universal address as pure conviction, or faith. The law 'objectifies' salvation and forbids one from relation it to the gratuitousness of the Christ-event" (Saint Paul 75).

${ }^{29}$ According to Žižek, "the subject is divided between (conscious) obedience to the Law and (unconscious) desire for its transgression generated by the legal prohibition itself. It is not $I$, the subject, who transgress the Law, it is non-subjectivized 'Sin' itself, the sinful impulses in which I do not recognize myself, and which I even hate" (149). 
cycle of perversion generated by the discourse of law, which only promises death? Herein lies the third element: the Christian discourse. St. Paul says: "There does not exist among you Jew or Greek..." (Gal. 3.28).

The problem with the Greek and Jewish discourses is not simply that they are discourses of the mastery and hence of the law, but likewise, following this issue of legality, the law is not universal but particular. What the law instantiates are not universal observances but individual adherences. Ultimately it divides agencies: the law-abider from the law-transgressor, the citizens from the sans-papier, the faithful from the heretic. Any discourse of law then is not universalizing and universalizable because they are confined to particularities. What is universal is not law, but grace and in this Paul enters into the universal discourse of Christianity.

Both the Greek and Jewish discourses may be labeled discourses of the Father because they form communities through obedience to the law and mastery over particular affairs. Only that which displaces the Father in favor of equality can be called "a discourse of the Son" (Saint Paul 42), which is found neither in Jewish prophecy nor in Greek logos, but found in Christian grace. Every event occurs in grace because it is unexpected and happens as a surprise (i.e., evental interruption). Grace is "that which occurs without being couched in any predicate, that which is translegal, that which happens to everyone without an assignable reason. Grace is the opposite of law insofar as it is what comes without being due" (Saint Paul 76-77). The discourse of law stipulates reward and merit for obedience but the discourse of grace brings life, even though undeserved. Every subject is "constituted by evental grace," (Saint Paul 63) or what he calls "laicized grace." ${ }^{30}$ As Badiou quotes Paul: "for you are not under law, but under grace" (Rom. 6.14). This very structure of "not...but" defines the division inherent in the subject. ${ }^{31}$ For Badiou, this

30"At bottom, what I call laicised grace describes the fact that, to the degree that we are given a chance of truth, a chance of being a little more than living individuals, pursuing our ordinary interests, this chance is always give to us through an event. This evental giving, based absolutely on chance, and beyond any principle of management or calculation of existence-why not call it a grace? Simply, it is a grace that requires no all-powerful, no divine transcendence. What interests me in Saint Paul is the idea-very explicit in his writings-that the becoming of a truth, the becoming of a subject, depend entirely on a pure event, which is itself beyond all the predictions and calculations that our understanding is capable of." ("Politics and Philosophy" 124-25)

31 "The subject of the new epoch is a 'not...but'." (Saint Paul 63) 
structure defines not the fixed state of a subject, but every subject designates becoming. We are under the rule of law because we are bound to the path of the flesh; but this "destiny" engraved in our embodiment is suspended in favor of grace due to our fidelity to the event. Badiou would summarize the divided subject and its universal singularity as follows,

The event is at once the suspension of the path of the flesh through a problematic 'not,' and the affirmation of the path of the spirit through a 'but' of exception. Law and grace are for the subject the name of the constituting weave through which he is related to the situation as it is and to the effects of the event as they have to become. We shall maintain, in effect, that an evental rupture always constitutes its subject in the divided form of a 'not...but,' and that it is precisely this form that bears the universal (Saint Paul 63-64).

The third defining character of the subject is fidelity. For Badiou, "[t]o be faithful to an event is to move within the situation that this event has supplemented, by thinking (although all thought is a practice, a putting to the test) the situation 'according to' the event" (Ethics 41). When an event happens it invites an agent to an "evental fidelity" to it (Saint Paul 90). However, this fidelity is in no way an ontological justification for conservatism. When an event occurs, it invites a subject to enter to an engagement with it through intervention solidified within a faithful stance towards the originary event. But this evental fidelity accrues into a transformation of the former state of affairs into which the originary event materialized as an interruption. Hence, the evental subject has to "think" the situation in accordance with the spirit of the interrupting event. Note that Badiou clarified in a parenthetical statement that "thinking" in no way suggests a mere reflective detached stance, but is ultimately founded on a praxis in order to "put to the test" the viability of the emergent event as a transforming agency disturbing the status quo. Furthermore, fidelity to the event is not about allegiance but about declaration: "To declare the event is to become the son of that event" (Saint Paul 59). This sonship that an event effects is important to Badiou because it forms part of his argument that the Christian discourse of the Son makes all its subjects equal, which prepare the ground of universality, that is, "the evental declaration filiates the declarant" (Saint Paul 59). This manifests Paul's antiphilosophy, according to Badiou, because the discourse of Greek logos (and even the Jewish prophetism) only produces "disciple-subjects" and not "son-subjects." The discourse of the 
Father founded on mastery and effectuation of disciple-subjects will always block the universalizing effectivity of the event proper, and hence, Badiou counsels that one "must depose the master and found the equality of the sons" (Saint Paul 59). One may remark that this logic of equality follows Whitehead's concept of divine companionship. For Whitehead, God is not the destination of religious sojourn, but the companion to the pilgrimage itself towards His own vision of the "Harmony of Harmonies" (Adventure of Ideas 196). In becomingreligion, God is not its teleological object as if to suggest the goal of religion were a divine homecoming in a transcendent locus where God expectantly stands at the door with wide open arms. Whiteheadian ethnopoiesis postulates that God is our companion in becoming-religion, and this equal relation with God constitutes the universality of the Christian discourse. Badiou lucidly explains it as follows,

The most powerful expression of this equality [of the sons], necessary correlate of ... universality, can be found in I Corinthians 3, 9. We are all $\theta \varepsilon o v$ бuvepyoí, God's coworkers [co-ouvriers de Dieu]. This is a magnificent maxim. Where the figure of the master breaks down come those of the worker and of equality, conjoined. All equality is that of belonging together to a work. Indubitably, those participating in a truth procedure are coworkers in its becoming. This is what the metaphor of the son designates: a son is he whom an event relieves of the law and everything related to it for the benefit of a shared egalitarian endeavor. (emphases added and text slightly modified, Saint Paul 60)

For Badiou, the importance of the subject of the event lies, using the imagery of Paul, in the treasure that it carries within itself (2 Corinthians 4,7). This treasure is the eventum tantum. For a Christian, the treasure that each carries faithfully is not a set of teachings, nor a rubric of rituals, or even a code of conduct, but the Christ-event itself. ${ }^{32}$ Badiou avers,

Whoever is the subject of a truth (of love, of art, or science, or politics) knows that, in effect, he bears a treasure, that he is traversed by an infinite power. Whether or not this truth, so precarious, continues to deploy itself depends

32 "The treasure is nothing but the event as such, which is to say a completely precarious havingtaken-place. It must be borne humbly, with a precariousness appropriate to it." (Saint Paul 54) 
solely on his subjective weakness. Thus, one may justifiably say that he bears it only in an earthen vessel, day after day enduring the imperative-delicacy and subtle thought-to ensure that nothing shatters it. For with the vessel, and with the dissipation into smoke of the treasure it contains, it is he, the subject, that anonymous bearer, the herald, who is equally shattered (Saint Paul 54).

\section{Badiou and the Truth of Religion}

On the question of truth of religion, Badiou has this to say with regard to St. Paul: "For him, if there were an event, and if the truth consists in declaring it (and then in being faithful to it), it is necessary to sustain that the truth is evental in so far as it arrives and that it is singular." "Saint Paul" 324-25, translation author's own). Truth, then, is evental for two reasons: because it occurs, or happens, and it is marked by singularity.

Before we explicate this eventality of truth, one has to note that Badiou distinguishes an ordinary individual, a someone, from a subject, technically reserving the latter word to that through which a truth procedure passes. ${ }^{33}$ The notion of becoming-subject, or "to enter into the composing of a subject," suggests that "at a given moment, everything he is-his body, his abilities-is called upon to enable the passing of a truth along its path" (Ethics 40). To consider a subject as such (and not simply as "someone"), necessarily entails the occurrence of truth procedure. Strictly speaking, it is a truth that provokes a subject, and not the other way around: "The subject is nothing other, in its being, than a truth grasped in its pure point; it is a vanishing quantity of truth, a differential eclipse of its unfinishable infinity" (qtd. in Hallward, Badiou 142). This note is important because when Badiou speaks of truth as subjective, there is nothing capricious or arbitrary about it. Truth is subjective insofar as it provokes a subject attaining singularity, and as singular, it is universal. Subjective is not particular or individual, but a sister-concept of universal. Furthermore, Badiou also makes a distinction between knowledge

${ }^{33}$ Hallward explains this as follows: "Since every truth is exceptional, the subject must be firmly distinguished from an ordinary individual. What Badiou calls an ordinary 'someone' (quelqu'un) is simply an indifferently infinite element already presented in a situation. By contrast, a subject in no way pre-exists the truth process that inspires him: subjectivation is the abrupt conversion of a someone" (Badiou 142). 
and truth. The realm of knowledge is characterized by order, objectivity, and particularity; the realm of truths (strictly in the plural) is characterized by the absence of order or continuity, subjectivity, and singularity. Truths emerge from the realm of knowledge by way of subtraction from the particularity and objectivity of the known. Therein lies the importance of Saint Paul for Badiou because the former was able to subtract truth from the particularizing grasp of a people, a territory, or a social class. The universal truth that Paul declared was subtracted from the objectivity of particular knowledges. ${ }^{34}$ Why is this distinction present in Badiou? While knowledge bespeaks of the discourse of the Father, of law and mastery, truth echoes the discourse of the Son, and hence of universality. Peter Hallward provides an illuminating analogy in order to show the importance of the distinction between the two. He said that in the epistemic rupture, Badiou splits apart the two adjectives in the familiar platitude "tried and true." "Every truth pushes the subject into the realm of the untried, and for that reason, 'tries' (is the trial of) the subject. Or again: every subject 'believes something without knowing why'...." (Hallward, Badiou xxv).

When we speak of evental truth as that which occurs, we speak of truth as founded on event (in contrast to being and hence of objective knowledge). Badiou explains that a "singular truth has its origin in an event. Something must happen, in order for there to be something new. Even in our personal lives, there must be an encounter, there must be something which cannot be calculated, predicted or managed, there must be a break based only on chance," that is, through grace ("Politics and Philosophy" 124). Every truth then happens because of an encounter in the same way that the truth of the Christ-event happened in the encounter of Paul with the resurrected Christ. The eventality of truth, following the analogy of Lacan, punches a hole within knowledge; it institutes an immanent break within the objective continuity of knowledge in order to assure the fresh emergence of a truth ("Christ is risen!") and its implications. ${ }^{35}$ Likewise, when we speak of evental truth as character-

34"Paul's unprecedented gesture consists in subtracting truth from the communitarian grasp, be it that of a people, a city, an empire, a territory, or a social class. What is true (or just; they are the same in this case) cannot be reduced to any objective aggregate, either by its cause or by its destination" (Saint Paul 5).

35 "Essentially, a truth is the material course traced, within the situation, by the evental supplementation. It is thus an immanent break. 'Immanent' because a truth proceeds in the situation, and nowhere else-there is no heaven of truths. 'Break' because what enables the truth- 
ized by singularity, we speak of truth as something that is generic, that is, indiscernible with regard to its situation. As indiscernible, a truth traverses the avenue of particularity constituting itself as universal within its singular instance. Truth does not belong to particularity but to singularity, and as such, it is universal. Badiou insists that subjective intervention is demanded: "A truth procedure is only universal insofar as it is supported, at that point through which it indexes the real, by an immediate subjective recognition of its singularity" (Saint Paul 22).

After having clarified certain ideas on the nature of truth, we may specify the essential characteristics of truth in Badiou (see Saint Paul 14-15). Firstly, Badiou posts a "theory of equality before truth," that is, since no Christian subject preexists the Christ-event, all are constituted as "son-subjects" or co-workers in the declaration and fidelity to the event and its implications. As sons then, all Christian subjects are equal: neither Jew nor Greek, neither slave nor free, neither man nor woman. Secondly, as it has been elaborated above, truth is subjective, that is, it belongs to the Christian discourse of declaration arising from the conviction (and not conformity) that the adherent has relative to the Christ-event. Thirdly, truth is a process; de-substantialized, a truth procedure. As a process, fidelity to the declaration of truth and its implications is necessary and can take three forms: a) faith (míotis) because there is no space

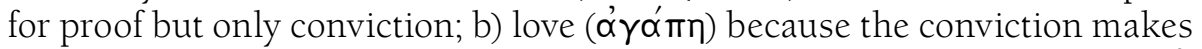
of the believer a militant of the truth, a practitioner practices; and c) hope ( $\dot{\varepsilon}$ $\lambda \pi i s$ ) because the conviction of the believer entails tenacity or obstinacy; an imperative to persist. Fourthly, truth is "indifferent to the state of the situation." The subtraction essential in the emergence of truth postulates a break from opinion and a distance from the state of the situation. The vocation of both the philosopher and the Christian must really arise from an evental break. As one is called to be a Philosopher: "Since Plato, philosophy has stood for a rupture with opinion.... Everything consensual is suspicious as far as the philosopher is concerned" (Metapolitics 78-79). And to be a Christian: "Do not conform yourselves to this age but be transformed by the renewal of your

process-the event-meant nothing according to the prevailing language and established knowledge of the situation.

"We might say, then, that a truth-process is heterogeneous to the instituted knowledge of the situation. Or-to use an expression of Lacan's-that it punches a 'hole [trouée]' in these knowledges." (Ethics 42-43) 
mind, so that you may judge what is God's will, what is good, pleasing, and perfect" (Rom. 12.2).

\section{Ave crux spes unica: the Evental Subject and the Christ-event}

Simone de Beauvoir, in her book The Second Sex, is famous for having said that "[o]ne is not born, bur rather becomes a woman." (295). This means that the feminine is not reducible to any biological, economic, or psychological determination. For her, "it is civilization as a whole that produces this creature" (295). In a way also, for Badiou, no one is born a subject, one becomes a subject. An individual becomes a subject through an event. One is not born a St. Paul, but rather becomes St. Paul; one is not born Alain Badiou, but rather becomes Alain Badiou; one is not born Corazon Aquino, bur rather becomes Corazon Aquino. In all these, it was through an originary event (or a series of originary events) that constitute these individuals' becoming-subject.

To summarize then, there are three fundamental insights that we stress in relation to becoming of the evental subject. Firstly, the event is the cause of the subject. The constitution of an evental subject is largely determined by the event defining the form of someone's subjectivity. In the words of Badiou, a "Christian subject does not preexist the event he declares (Christ's resurrection)" (Saint Paul 14).

It is from the truth of this Resurrection that one finds the meaning of St. Paul's own evental subjectivization, a subjectivization that is rooted in the conversion event in his journey to Damascus. His subjectivization participates in the extending over of the eventum tantum of Christianity. His is one node, albeit a crucial one, in the becoming-religion of Christianity that will find its ultimate fulfillment when "we form a building which rises on the foundation of the apostles and prophets, with Christ Jesus himself as the capstone" (Eph. 2.20).

One's identity as a Christian cannot be divorced from this Christ-event. One cannot be a Christian if one does not have Christ, if one does not share in the "brief Galilean vision of humility [that flickers] throughout the ages, uncertainly" (Whitehead, Process and Reality 342). This brief Galilean vision continues to flicker because in the extending over of the eventum tantum of 
Christianity, the vision of Christ still interrupts our life, rousing us from our fiducial slumber. The vision is still capable of persuasively inviting people to its cause, gradually unfolding the actualization of its promise.

Secondly, it is one thing to be interrupted by an event, it is another thing to enter into it and abide by it. Badiou calls this "fidelity": "[t]o be faithful to an event is to move within the situation that this event has supplemented, by thinking...the situation 'according to' the event" (Ethics 41). Fidelity to the Christ-event is not simply a matter of words but of action. More importantly, fidelity is orthopraxis-truthful living. The truth of Christianity lies in the peculiar life lived by Christians molded into the event of Christ's Paschal Mystery. To be faithful to the Christ-event is to live ordinarily, but according to the event-in the mode that the event has determined for the evental subject. Christianity becomes "adverbial" in the sense that an individual Christian lives his or her life ordinarily, but in a manner stamped by the Christ-event. The evental subject of the Christ-event lives life "Christly."

Thirdly, Badiou recuperates an important element in spiritual life as reflected in his treatment of St. Paul, namely, an event has a character of a climax or turning point. For a Jamesian, one can read this as the point of transition from the "once-born" to the "twice-born" (James 166). It cannot be denied that those who possess zest for religion are those people who have had peak or "aha!" experiences. They are mostly those who have undergone a "religious crisis," those who have passed beyond the critical juncture of belief and unbelief. The mark of fidelity lies not in the eventum tantum, but on how the Christ-event becomes a manner that shapes the daily life of an evental subject. Fidelity is allowing the rippling effect of the eventum tantum to pass through and beyond us.

When an event happens to us, the impact leaves us changed and molded according to the mode of this event. As an event, it has a fixed relation to space and time. It cannot change and will forever be there in the past as a significant moment in the life of a subject. But in the event's landing, it commences a rippling effect around its immediate spatial and temporal environment. The degree of relevance of this event is congruent to the degree of extending over of the eventum tantum. What an event delivers is an evental promise, something that is given us because of the event, effectively molding our world, and at the same time still awaiting fulfillment. The eventum tantum makes a promise, 
changing us at the very arrival of this promise even if it has yet to be actualized. This actualization rests upon the shoulders of that person made subject by the event. The very process of evental subjectivization is the same process of evental promise reaching its fulfillment. Through active fidelity to the originary event, the subject realizes its own identity as evental subject, and at the same time brings to fulfillment the promise of the eventum tantum. In the subject, we find the crucial intersection of transcendence and immanence. It is to a subject that an event arrives, and it is to the subject that the promise of the event unfolds.

To recapitulate, a Christian is a Christian because of a Christ-event. By Christ-event, we mean primarily the historical moment defined by the life of Christ where we find "a revelation of the nature of God and his agency in the world" (Whitehead, Adventure of Ideas 167). For Christians, the incarnation is the finest instance of the junction of transcendence and immanence. Jesus' own encounter with the Father, exemplified in the event of the Baptism in the Jordan, confirmed his identity as the Son of God and his mission as a coworker. This evental interruption in the life of Jesus, and his fidelity to the divine attestation that he is "the beloved Son of God," radically transformed his life from a simple carpenter to a controversial preacher. This transformation consolidates him as the finest model of evental subject. The short ministry where he expounds his vision of "Harmony of Harmonies" (to borrow the words of Whitehead) is capped by his own testimony to this vision by offering his life on the cross. The apparent tragedy of the cross was only a part in the unfolding of the evental promise; for the vision was a not a vision of death-but of life. Its fulfillment was the Resurrection.

In the figure of the Cross, Christianity finds its symbol of becomingsubject. Firstly, the vertical beam speaks of the arrival (ad-venire) of the divine in the world, the in-breaking of the Other. So radical was the advent of God that until now, the world has yet to understand its full meaning and implication. The world has yet to reach the depths of the mystery of God-becomeman. This evental interruption not only made real the "impossible" fact of the Incarnation. It likewise initiated the unfolding (e-venire) of this mystery, the unfolding of the evental promise that the interruption instigated. This horizontal beam in becoming-religion manifests that each moment in the life of a Christian, from the most banal to the most unexpected, is a gradual unfurling of the seamless mystery of the Resurrection of Christ. If in the life of 
Christ time is ruptured in evental interruption, in the life of a Christian time is made to progress in the unfolding of the evental promise. That these two directions, the vertical and the horizontal, intersect is not the crucial point. More importantly, in each intersection that comes to pass, evental subjectivization ensues. A cross is not a cross without the Christ who carried it, was nailed to it, died on it, and triumphed over it. In the cross, Jesus was eventally subjectivized as Christ. In this same cross, each Christian finds his or her own hope. Through this cross, a Christian lives in persona Christi. Beyond this cross, each Christian is resurrected in the fullness of time as co-heirs in the reign of God. Ave crux spes unica.

\section{Works Cited}

Badiou, Alain. Being and Event. Trans. Oliver Feltham. London: Continuum, 2007.

---. Century. Trans. Alberto Toscano. Cambridge: Polity, 2007.

--_. D’un désastre obscur. Paris: Éditions de l'aube, 1998.

---. "Dix-neuf réponses à beaucoup plus d'objections." Le cahier du collège international de philosophie 8 (1989): 247-68.

---. Ethics: An Essay on the Understanding of Evil. Trans. Peter Hallward. London: Verso, 2002.

--- Handbook of Inaesthetics. Trans. Alberto Toscano. Stanford: Stanford UP, 2005.

---. "L'entretien de Bruxelles." Les Temps Modernes 526 (1990): 1-26.

---. Manifesto for Philosophy. Trans. Norman Madarasz. Albany: SUNY Press, 1999.

---. Metapolitics. Trans. Jason Barker. London: Verso, 2005.

---. "Politics and Philosophy: An Interview by Peter Hallward." Angelaki: Journal of the Theoretical Humanities 3.3 (1998): 113-33.

---. "Saint Paul: Fondateur du sujet universel." Études théologiques et religieuses 73.3 (2000): 323-33.

--- Saint Paul: The Foundation of Universalism. Trans. Ray Brassier. Stanford: Stanford UP, 2003. Barker, Jason. Alain Badiou: A Critical Introduction. London: Pluto Press, 2002.

Blanton, Ward. "Disturbing Politics: Neo-Paulinism and the Scrambling of Religious and Secular Identities." Dialog: A Journal of Theology 46.1 (2007): 3-13.

Dastur, Françoise. "Phenomenology of the Event: Waiting and Surprise." Hypatia 15.4 (2000): 178-89.

de Beauvoir, Simone. The Second Sex. Trans. H.M. Parshley. London: Vintage, 1997.

Deleuze, Gilles. "A Philosophical Concept..." Trans. Julien Deleuze. Who Comes after the Subject? Ed. Eduardo Cadava, Peter Connor and Jean-Luc Nancy. New York: Routledge, 1991, 94-95. 
--- Difference and Repetition. Trans. Paul Patton. New York: Columbia UP, 1994. Devlin, Keith J. Fundamentals of Contemporary Set Theory. New York: Springer-Verlag, 1979. Gibson, Andrew. Beckett and Badiou: The Pathos of Intermittency. Oxford: Oxford UP, 2006. Hallward, Peter. Badiou: A Subject to Truth. Minneapolis: University of Minnesota Press, 2003. ---. "Generic Sovereignty: The Philosophy of Alain Badiou." Angelaki: Journal of the Theoretical Humanities 3.3 (1998): 87-111.

Hegel, G. W. F. Philosophy of Right. Trans. T. M. Knox. Oxford: Oxford UP, 1967.

James, William. The Varieties of Religious Experience. New York: Dover Publications, Inc., 2002. Lacoste, Jean-Yves. La phénoménalité de Dieu. Paris: Cerf, 2008.

Moreiras, Alberto. "Children of the Light: Neo-Paulinism and the Cathexis of Difference (Part I)." The Bible and Critical Theory 1.1 (2004): 1-16.

---. "Children of the Light: Neo-Paulinism and the Cathexis of Difference (Part II)." The Bible and Critical Theory 1.2 (2005): 1-13.

Rimbaud, Arthur. Collected Poems. Trans. Oliver Bernard. London: Penguin Classics, 1986. Taylor, Charles. A Secular Age. Cambridge, Massachusetts: The Belknap Press of Harvard University Press, 2007.

Whitehead, Alfred North. Adventure of Ideas. New York: The Free Press, 1933.

---. An Inquiry Concerning the Principles of Natural Knowledge. Cambridge: Cambridge UP, 1919.

---. Process and Reality: An Essay in Cosmology. Ed. David Ray Griffin and Donald Sherburne. New York: The Free Press, 1978.

Žižek, Slavoj. The Ticklish Subject: The Absent Centre of Political Ontology. London: Verso, 1999. 